\title{
The Genetic Closeness of the Finnish Ugric, Slav and Germanic Populations According To Anthropological and Genetical Data
}

\section{Nazarova AF*}

Institute of Ecology and Evolution of the Russian Academy of Sciences, Moscow, Russia

\begin{abstract}
The calculation of genetic distances of 55 human populations belonging to four great human races considering loci of proteins, enzymes and blood groups, and construction the dendrogram of this population distinguished some relationship of German, Slavic and Finnish-Ugric populations. So, Russians are in one subcluster with Poles, Iranians, Komi, Chuvashes, Udmurtians, Nentses and Ossetians. Germans are in one subcluster with Serbs, Moldavians, Hungarians, Croatians and Czechs. Greecs are in closeness with Slavic populations on this dendrogram, too. There were common migrations of this populations from places of first differentiation in Asia. In Europe German populations were migrated by another way than ancestors of Russians, which were migrated in Europe across North of Siberia. The ancestors of Germans probably migrated by the same way as Hunnu. Now are investigated settlements of ancient Caucasoids in Central Asia. The studying of mt DNA of rural Russian population in Yaroslavsky region discovered all haplogroups of Russians and even Caucasoid $(\mathrm{H}, \mathrm{W}, \mathrm{I}, \mathrm{U}, \mathrm{X}, \mathrm{T} 1)$. The last decoding of petrogliphs in Baical region discovered the presence of ancestors of Caucasoids in Siberia in paleolithic.
\end{abstract}

Keywords: Human populations; Genetic closeness; Finnish-Ugric; Slave; Germanic populations; Genetic distances; Anthropological data

\section{Introduction}

The Dendrogram made based on the matrix of the calculations of the genetic distances of 55 human populations belonging to four of the major human races according to the loci of proteins, enzymes and blood groups revealed a certain genetic closeness of the Slavic, FinnoUgric and German populations [1]. Russians turned out to be in the sub cluster with the Poles, Iranians, Komi, Chuvaches, Udmurtians, Nentses, Ossetians and Azerbaijanians. Some historians think Russians are the descendants of the Rus-Skifian tribes, so their being in this cluster with other descendents of the Skifians-the Iranians and the Ossetians-is understandable.

The Paleolithic migration of the ancestors of the Russians from the center of Asia, Southern Siberia, across the north of Siberia to the north of Europe explains why the Nentses are in this cluster: the Nentses are evidently a trace of that migration [2-4].

That the Komi, Chuvaches and Udmurtians are in this subcluster may be connected with the fact that around 1000 years ago the tribes of Finnish-Ugric origin-the Merya, Muroma, Meschera and othersbecame part of the Russian ethnos. In the works of academician Alekseyeva et al. [5,6] the presence of a Finnish-Ugric anthropological substrata in the Russian populations is shown.

\section{Methods}

We were investigated the phenotypes of such human populations as Russian, Evenks, Yakuts, Alsatians, Chuck chi, Eskimos and Talyshes in poly acrylamide gel. Methods of those processes are described by Nazarova [7].

The gene frequencies we calculated on computer. The gene frequencies of another human populations we have taken from publish data other authors that were cited in our book "The Genetically Portrait of the People of the World" [8]. The genetic distances of 55 populations of Europe, Asia, America, Africa and Oceania, and of 35 Slave, German and Finnish-Ugric and some other populations we were calculated by method of Cavalli-Sforza and Bodmer [9]. The dendrogram of genetic relationship of those 55 human populations, and of 35 populations of
Slaves and others we were constructed by method of Mashurov and Cherkashenko [10] with computer program which was doing by Than H.H.

\section{Results and Discussion}

The Germans are in the same sub cluster as the Serbs, Moldavians, Hungarians, Croatians, Czechs and Ukrainians [1]. This closeness may be explained by the common origin of the ethnos enumerated and their migration from the first place of differentiation in Asia to Europe by a route other than the ancestors of the Russians who went to Europe via north Siberia. The ancestors of the Germans, and also the current central- European Slavic ethnos, migrated to Europe from Asia roughly following the same route that the Hun's took earlier. In the works of Sarianidi et al. [11] (2004) the discovery of a settlement of ancient Caucasoid in central Asia on the territory of Turkmenia is described. In the opinion of Scherbadkov et al. [12] they are the ancestors of the German tribes. Research on the mitochondrial DNA of the rural Russian population of the Yaroslavl region revealed the presence of practically all haplogroups characteristic of Russians and even Caucasoid as a whole [13] $\left(\mathrm{H}, \mathrm{W}, \mathrm{I}, \mathrm{U}, \mathrm{X}, \mathrm{T}^{\star}, \mathrm{T} 1\right)$. The latest deciphering of the hieroglyphs in the Bailkal region indicates that the ancestors both of the Shumers and of the Japanese were there in the Paleolithic [14], and about the presence in this region of the most ancient written language. The presence of the ancestors of the Russians in almost all Eurasia in the Paleolithic and them having the most ancient Runic written language has also been shown (Chudinov et al. [15]. The Finns are in the sub cluster with the Swedes, Estonianians, Talyshes and Belorussians.

*Corresponding author: Nazarova AF, Institute of Ecology and Evolution of the Russian Academy of Sciences, Moscow, Russia, Tel: 8-915-139-65-00; E-mail: afnazar@yandex.ru

Received December 06, 2013; Accepted January 31, 2014; Published February 02, 2014

Citation: Nazarova AF (2014) The Genetic Closeness of the Finnish Ugric, Slav and Germanic Populations According To Anthropological and Genetical Data. J Biodivers Endanger Species 2: 118. doi: 10.4172/2332-2543.1000118

Copyright: () 2014 Nazarova AF. This is an open-access article distributed under the terms of the Creative Commons Attribution License, which permits unrestricted use, distribution, and reproduction in any medium, provided the original author and source are credited. 
In Supplemtary table 1 we give the matrix of the genetic distances of 35 Slavic, Germanic and Finnish-Ugric populations. The Dendogram made according to the data in Supplemtary table 1 corresponds on the whole with the conclusions made from the matrix and the dendrogram of 55 populations (Figure1).

As can be seen from the dendrogram in Figure 1, the Poles (2) are in the big sub cluster together with the Russians (1), the neighboring branch splits up into several sub clusters in which there are the branches of the Serbs (22) and the Germans (2), and further are the branches of the Croatians (23), the Czechs (25), the Ukrainians (18), and the Hungarians (26). In the next neighboring sub cluster there are the Swedes (28), the

Finns (12), the Estonians (20), and the Belorussians (19). And in the last sub cluster of that big cluster there are the Scotch (21) and the Bulgarians (24).

The cluster next to the cluster with the Russians and other Slavic, Germanic and Finnish populations has the branches of the Komi (4), the Chuvaches (5), the Iranians (3), the Ossetia's (8), the Nentses (7), and the Urdmurtians (6). So the Finnish-Ugric peoples living in the Volga region and the Ural region now show a genetic closeness to the Ossetians, the descendents of the ancient nomads, the Skifs, and with the Nentses now living in the north of the European part of Russia and Siberia. That closeness could be due to the fact that all these peoples were originally ancient ancestral Asiatic populations who inhabited southern Siberia (the Altai and the neighboring regions) in the Paleolithic and then went on a many thousand year long migration that brought them to their current place of habitation. We first described these processes in works [2-4].

The sub clusters containing the branches of the Mongols (16), Alsatians (13), Yakut's (15), Mansi (29) and Mari (27) are more distant.

The branches of the Lapps (35) and Africans (33) separates from the common pre Asiatic population much earlier, but the branch of the American Indians (30) splits off earliest of all.

The cluster containing the sub clusters of the Slavic-Germanic (Russians, Poles, Serbs, Germans and others) and the Finnish-Ugric (Komi, Chuvashes, Udmurts) as another branch has the sub cluster of the Tartars. The sub cluster of the Italians (10), Arabs (9), and Evenks (14) split off from the cluster containing the Slavic-Germans and FinnishUgric and Tatars even earlier. Already in the book "Anthropology and Ethnography" (1913) edited by Heilbronn and Berg, the Evenks are called "Siberian Frenchmen" and their dissimilarity to the rest of the northern mongoloids is stressed.

So the matrix of genetic distances of 35 human populations containing the Slavs, Germans and Finno-Ugric, and also the Saami and American Indians on the whole supports the conclusions made by us earlier based on matrixes 7 and 55 populations [1-4]. Evidently, in the mid Paleolithic in the Altai region or in the neighboring regions there was a population ancestral both for the Caucasoid and for the Northern Mongoloids and American Indians. The northern Alsatians today are direct descendants of this ancestral population. The ancestors of the American Indians, the first to separate from this Asiatic ancestral population, migrated across Siberia to the north-east of it, moving, perhaps behind the herds of the ancestors of the American buffalo and the caribou whose ancestral land also is considered southern Siberia. The ancestors of the Indians crossed the Bering Isthmus, which existed in the Paleolithic, to the American continent.

Now are investigated the genetically markers of Y- chromosome of many human populations [16-18]. There were discovered that Slavic populations had precise definite series of such markers that inherited only by man line, because Y-chromosome is inherited only by man line, from father to son. These markers are constant, so there was possible to watch the way of human populations from paleolithic times to our days. The rare mutations of these markers permit to see the ways of differentiations of populations. So, the Slavic populations had haploidgroup R la1.

In the Paleolithic, the ancestors of the Northern Mongoloids migrated from southern Siberia to its north, finally settling where they live now. The Evenks, Nganasans, and the Yakuts are now living in Siberia as well as the Nentses who moved toward the north-east of Europe.

The ancestors of the Caucasoid (Russians) went, evidently, also from the south of Siberia to its north, and further via the circumpolar zone crossed to the north of Europe. That was also probably the route of migration of the Saami now living in the north of Europe (Finland, the Kola Peninsula, Norway and Sweden).

On the dendrogram at Figure 1 Greecs are one branch of big sub cluster, and other branch of this sub cluster consist of Russians and other Slavic populations, as Poles, Serbs, Croatians, Czechs, Bulgarians, Belorussians, and Germans, Finns, Estonians and Scottish, too.

On the dendrogram of 16 population of Caucasus and some other populations Greeks are in one sub cluster with Russians [19]. This fact confirms the data of Malyarchuk [13] indicating on mitochondrial DNA polymorphism data the closeness of the Slavic populations and the populations of Southern Europe. On the dendrogram of 55 human populations Greeks and Mari are in one sub cluster [16]. This at the first glance strange union can be explained by the fact that the Mari, who are real Caucasoid, may have been close to some ancient Caucasoid, who migrated to Europe most likely from Asia even thousand year B. C. -the Akheits, representatives of the Crete - Mycenean civilization, whose descendants are the Greeks.

The other branch of the Caucasoid, the Finnish-Ugric tribes, most likely went from Asia to Europe somewhat more south across the Urals and settled in the Volga region, the Kama region and the Ural region and further on in a significant part of European Russia (Merya, Muroma who later became part of the Russian ethnos), and finally the Baltic states and Scandinavia (Finns, Karelians, Estonians). As a result of dermatoglyphic research of the Finnish-Ugric populations it was concluded that the Finnish-Ugric peoples had the same components as those that formed the anthropological appearance of the population of northern Eurasia [20,21].

In the works of the Indian scientist Tilak it is shown through the analysis of epic works of the Caucasoid of Asia that the ancestors of the Indians and Iranians also inhabited the Circumpolar zone for a while. Later the ancestors of the Indians migrated to the south west of the Urals, while the ancestors of the Iranians - east of the Urals.

The ancestors of the Germanic tribes, in the opinion of Kurovsky are the Skifian tribes of Asia. So it is likely that the ancestors of the Germans migrated to Europe not across the north, but across the south of Siberia, and further across Middle Asia, where remainders of the civilization of the Caucasoid were unearthed in a region of Turkmenia today [7-8].

One should keep in mind that the migration of all these tribes which began back in the middle Paleolithic was very long lasting many thousands of years. People went on foot with their families, 


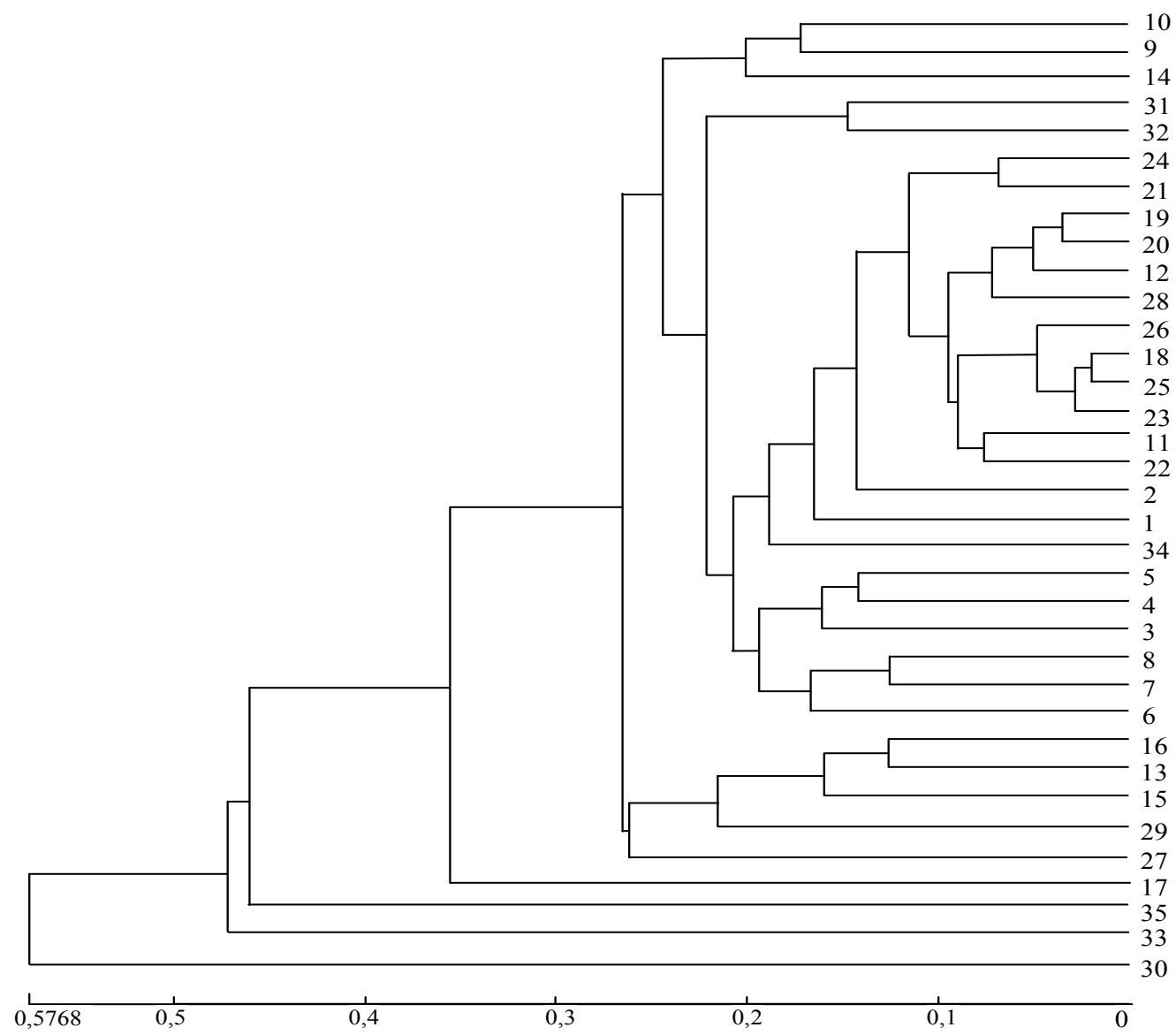

By horizontal axis are the genetic distances. Names of populations to Figure1: 1. Russian. 2. Poles. 3. Iranians. 4. Komi. 5. Ghuvashes. 6. Udmurtians. 7. Nentses. 8. Ossetians. 9. Arabes. 10. Italians. 11. Germans. 12. Finns. 13. Altaians. 14. Evenks. Yakuts. 16.Mongols. 17. Indians. 18. Ukrainians. 19. Belorussians. 20. Estonians. 21. Scottish. 22. Serbians. 23. Croatians. 24. Bulgarians. 25. Czechs. 26. Hungarians. 27. Mari. 28. Swedes. 29. Mansi. 30. American Indians. 31. Tatars. 32. Jews of Near East. 33. Negroes of Africa. 34. Greecs. 35. Saami(Lapps)

Figure 1: \%Dendrogram of closeness of Slavic, Finnish-Ugric and Germanic Populations.

with their goods and chattels, stopping for a long time in places where food was abundant. And only later were animals which would make the migration a bit easier first domesticated. Some of the tribes went, evidently with the ancestors of the large horned cattle. We discovered the presence of antigen $\mathrm{V}$ in the large horned cattle in southern Asia and in the Estonian red breed of cows.

The domestication of horses took place just 8 thousand years ago in Dnepr region where the most ancient stirrups and bitts were found.

Considering the Caucasoid components of the Alsatians revealed by us and the identical haplogroups in the mitochondrial DNA of the Alsatians and American Indians discovered by other authors, it is possible to make the presumption that there was an ancestral population in southern Siberia and in the neighboring regions in the Paleolithic that gradually split into a number of branches which migrated in different directions and gave rise both to the ancestors of the American Indians and the northern Mongoloids as well as the Caucasoid. At the same time as the ancestors of the northern Mongoloids split into different branches, the ancestors of the Finns split off from the ancestors of the Slavic and Germanic populations. The division of the ancestral population into different clusters, besides for biological reasons, was facilitated, evidently by the division of the Nostratic ancestral language into families - Indo-European and Finnish-Ugric, the group of languages of the ancestors of the American Indians-and then the splitting up of the language groups into separate languages.

Russian anthropologist Tomashevich, discovered a gradient of distribution of the frequencies of the supra orbital canals of the human skulls [18].The highest frequency of the supra orbital canals is among Saami, American Indians, and in Yakuts, Evenks, Chuckchi, and Eskimos. And in Kets, Yuragirs, Russians, Mansi, Ossetians and Armenians these frequencies are very close, near $30-38 \%$. That may be confirmation of their common Asiatic origin.

The biological reasons for the division of human populations was, evidently, the arising and accumulation of mutations. Malyarchuk discovered different sets of mutations of the mitochondrial DNA in the Slavic and Germanic populations in the control region.

Thus, based on the anthropogenic data we think that the Caucasoid today-the Slavs, Finns and Germanic populations--are from the same ancestral population inhabiting a region of Southern Siberia in the middle of the Paleolithic as that of the northern Mongoloids and American Indians. 
Citation: Nazarova AF (2014) The Genetic Closeness of the Finnish Ugric, Slav and Germanic Populations According To Anthropological and Genetical Data. J Biodivers Endanger Species 2: 118. doi: 10.4172/2332-2543.1000118

\section{References}

1. Nazarova AF (2008) Reports of the Russian Academy of Sciences. 420: 424 429.

2. Nazarova AF (1999) The Genetic data to the problem of differentiation of Northern Mongoloids, Caucasoids and Amerinds on Eurasia territory. Anthrological Bulletin6: 205-215.

3. Nazarova AF (2000) Genetic data on the migration of ancient Eurasian hunters through Siberia and the Circumpolar area. Rangifer 20: 53-54.

4. Nazarova AF (2005) The Genetic data to the problem of differentiation of Northern Mongoloids, American Indians and Caucasoids in the northern territory of Eurasia. AnthropolAnz 63: 353-364.

5. Alekseyeva TI (1954)The Anthropological Composition of Meshera and TatarsMishary in Relations of Slavs and Ugrish-Finns in Volga Region, Moscow.

6. Alekseyeva TI (1973) TheEthnogenisis of the Eastern Slavs according to Anthropological data. Moscow. Moscow State University, Moscow.

7. Nazarova AF (1989) The genetic structure of populations of Chukotka peninsula Eskimos and Chuckchi based on the study of 13 loci of serum and erythrocyte proteins and enzymes. AmJ PhysAnthropol 79: 81-88.

8. Nazarova AF, Alkhutov SM (1999) The Genetical Portrait of the Peoples of the World. Lipetsky Publishing House, Moscow.

9. Cavalli-Sforza LL, Bodmer WF (1971) The Genetics of Human Populations San Francisco, Freeman and Co.

10. Mashurov AM,Cherkaschenko VI (1987) Taking into consideration to genetic distance between breeds. Cattle breeding 2: 21-23.
11. Kosarev MF, Kodgin PM, Dubova NA (2004) Near the Sources of Civilizations. Old Garden, Moscow.

12. Scherbakov VI Asgard (2000) The City of Gods.

13. Nazarova AF, Kuznetsova MG, Alkhutov SM (2007) In the book Socio-Medical Aspects of the Ecological State of the Central Economic Region of Russia Tver: 132-141.

14. Kifishin AG, Kikeshev NI (2005) Ten Sintoistic Holy Places in Baikal Region. Bulletin of the International Slavic Institute.9: 86-94.

15. Chudinov VA (2006) Russian Runes. Moscow.

16. Sykes B (2001) Seven daughters of Eva. W.W. Norton and co, NY, London.

17. Wallace S (2002) Human travels: Genetic Odyssey. NY, Random House.

18. Tomashevich TV (1988) Laws of distribution of the frequencies of supra orbital canals of the human skull. Questions of Anthropology 80: 119-128.

19. Nazarova AF, Alkhutov SM (2008) Anthropology and Genetics of the Caucasus Peoples and the Problem of the Origin of the Caucasoids. AnthropolAnz 66 51-66.

20. Malyarchuk BA (2003)Mitochondrial DNA variability in Russians and Ukrainians: Implication to the origin of the Eastern Slavs. Annals of Human Genetics. 65: 63-78.

21. Khit GL, Dolinova NAAnthropology of Today's Finnish Ugric Peoples. Moscow. Russian Academy of Sciences: 27-99. 